\title{
小児結核の現状と対策
}

\author{
井上 寿茂, 高松 勇, 土居 悟 \\ 安浪 純, 林田 道昭, 豊島 協一郎 \\ （大阪府立羽曳野病院小児科）
}

\begin{abstract}
要旨：最近 5 年間に当科で経験した小児結核 67 例について疫学的に検討した。BCG 接種歴は全体 では41.8\% (28/67) に認めたが, 未就学児では $11.4 \%$ (4/35) にすぎず, 乳児期早期の BCG 接種 が望まれる。感染源は46例 $(68.7 \%)$ で推定でき多くは大量排菌者であった。結核菌は33例 $(49.3$ \%)に証明され，有症状受診者に高率であった。感染源発見から患児発見までの期間は年長児では 3 力月以上の場合がほとんどであるのに対し, 乳幼児では大部分が 3 力月以内で感染から発病ま での期間が短く急速に重症化するので, 感染源発見後一刻も早い家族検診の実施が必要である。
\end{abstract}

\section{An Epidemiological Study on Tuberculosis in Childhood}

Toshishige Inoue, Isamu Takamatsu, Satoru Doi, Jun Yasunami, Michiaki Hayashida and Kyoichiro Toyoshima

Epidemiological factors in 67 cases of childhood tuberculosis diagnosed for recent 5 years in our hospital were analyzed in order to find a clue to decrease the outbreak of the disease in childhood. The history of BCG vaccination were confirmed in $75 \%(24 / 32)$ of school children, but in only $11.4 \%(4 / 35)$ of preschool children. We empasize that BCG vaccination should be carried out as young as possible in infantile period.

Source cases were presumed in 46 out of 67 patients (68.7\%), and most of them were highly infectious.

Thirty three patients (49.3\%) were bacteriologically positive and the positive rate was higher in patients with symptoms than in patients discovered by the family contacts examination.

The intervals between discovery of patients and source cases were within 3 months in preschool children, but over 3 months in most school children. This difference between two age groups reflects the developing speed of the disease. Therfore, when a new tuberculosis patient would be found, a contacts examination should be carried out for younger children as soon as possible, especially who had intimate contacts with the bacilli positive patients.

Key words : 小児結核, 感染源, 発病予防, BCG

\section{緒言}

小児の結核は感染後早期に発病し急速に重症 化するため, 積極的な感染・発病予防対策と同 時に発病者の早期発見・治療が不可欠である。 医療従事者や一般住民の結核に対する関心の低 下が指摘されている折, 小児結核の現状を把握
し, 今後の結核対策の参考とするため, 最近当 科で経験した小児結核患者について検討し, 結 核対策の問題点を明らかにすることを試みた。

\section{対象}

1985年 1 月から 1989 年 12 月までの 5 年間に当 科で診断した小児結核患者67例（男31例，女36 
例）を対象とした。病型は肺門リンパ節結核を 含めた初期結核症30例, 慢性肺結核症20例, 結 核性髄膜炎 6 例, 粟粒結核 5 例, 結核性胸膜炎 5 例，頸部リンパ節結核 1 例である。

\section{結果}

発見動機ならびに結核菌の同定状況をまとめ て表 1 に示した。結核菌は33例 $(49.3 \%)$ で証 明できた。各病型別に発見動機をみると, 初期 肺結核症では家族検診が 15 例 $(50 \%)$, 有症状受 診が 7 例 (23\%) に対し，慢性肺結核症では家 族検診が 3 例 (15\%), 有症状受診が 12 例 $(60 \%)$ と対照的であった。結核性髄膜炎や粟粒結核は 大部分が有症状受診にて発見されており, 有症 状受診で発見された例は検診で発見された例に 比べ病状が進行している場合が多く, 結核菌の 証明される率も高かった。

年齢, 病型別に感染源発見から患者発見まで
表 1 病型別にみた発見動機

\begin{tabular}{|c|c|c|c|c|}
\hline & 症明数 & 定期检祄 & 家䔩模衫 & 有症状受讋 \\
\hline 初期肺姞核症 & $30\left(\begin{array}{ll}1 & 2\end{array}\right)$ & $8(3)$ & $15(5)$ & $7(4)$ \\
\hline 侵性肺姞核症 & $20\left(\begin{array}{ll}1 & 1\end{array}\right)$ & $5(1)$ & $3(1)$ & $12(9)$ \\
\hline 耛核性精股炎 & $6 \quad(5)$ & & $1(1)$ & $5(4)$ \\
\hline 栗粒转核 & $5 \quad(5)$ & & $1(1)$ & $4(4)$ \\
\hline 䊅核性问㬴炎 & $5 \quad(0)$ & & $1(0)$ & $4(0)$ \\
\hline 頑部リンバ第桔核 & $1(0)$ & & & $1(0)$ \\
\hline
\end{tabular}

の期間をみたのが図である。乳幼坚期を初期肺 結核症, 思春期を慢性肺結核症の患者が占め二 峰性の年齢分布を示した。乳幼児は大部分が感 染源発見後 3 力月以内に発見されており，感染 成立後速やかに発病することがよくわかる。こ れに対し年長児は感染から発病に至る経過が比 較的緩徐で, 感染源発見後打打む称 3 力月以上 たってから発見されている例がほとんどであ る。また就学児では感染源は32例中18例（56.3

感染源不明 $\stackrel{P}{I G} P C \quad H P$

G

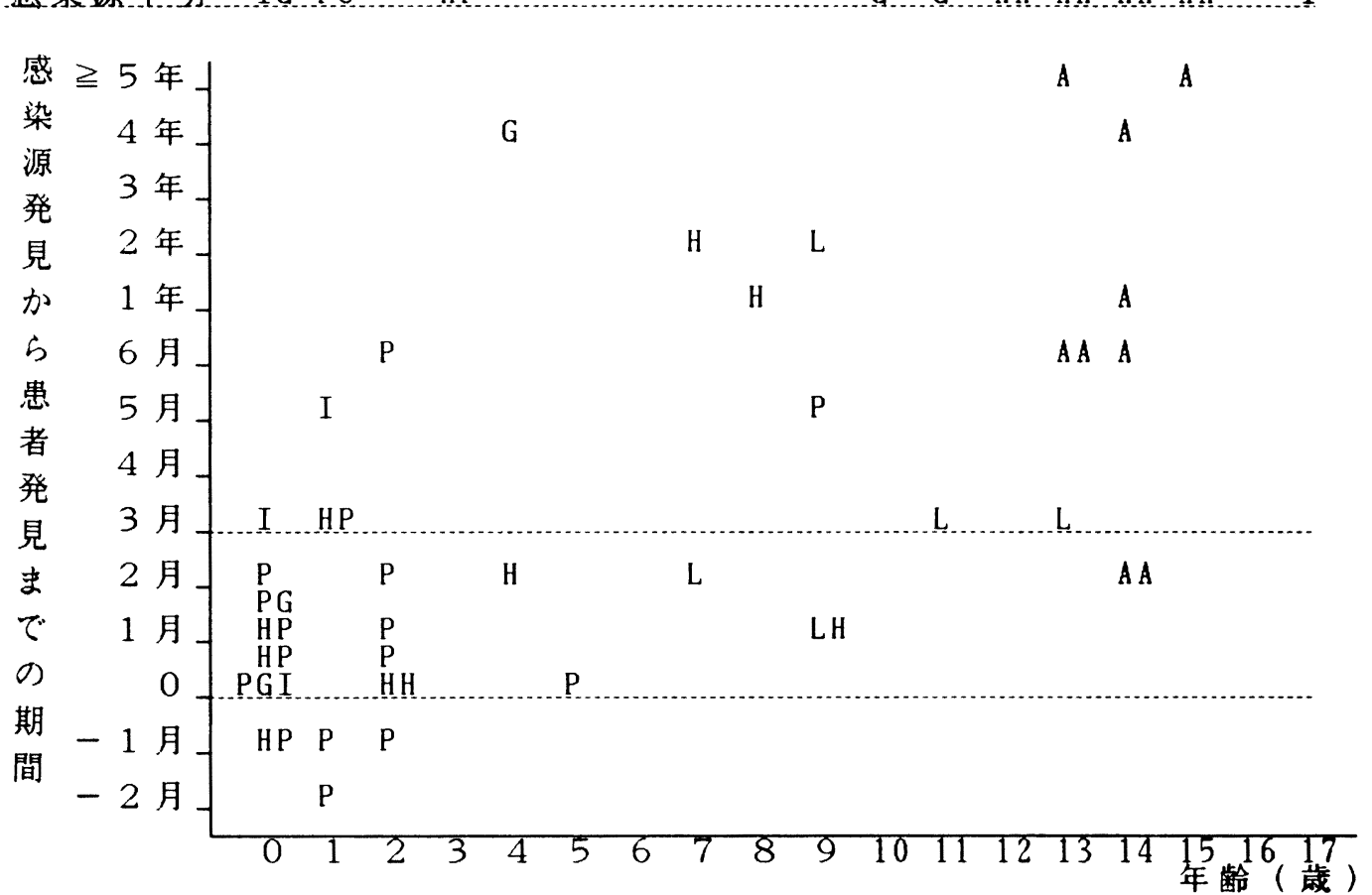

A：慢性肺結核症, C : 頸部リン八節結核, G : 結核性髄膜炎,

$\mathrm{H}$ : 肺門リンパ節結核, I : 粟粒結核, $\mathrm{L}$ ：結核性胸膜炎, $\mathrm{P}$ ：初期肺結核聇

図年齢・病型別にみた感染源発見から患者発見までひ期間 
\%)しか推定できなかったのに対し未就学児で は35例中28例 $(80.0 \%)$ で推定可能で, 行動範 囲の限られた乳幼児の場合には感染源が身近に 存在する場合が大部分である。実際患児が発見 された後感染源が発見された例が 5 例もあり， 積極的な感染源検索の重要性が伺われる。また 図には示さなかったが, BCG 接種歴は28例 (41.8\%)に認め，就学児では32例中 24 例 (75\%) に対し，末就学児では 35 例中 4 例 (11.4\%) と きわめて低率であった。感染から発病までの期 間が短く重症化しやすい乳幼児においてこそ BCGによる発病予防が必要ではないだろうか。

感染源について表 2 によとめた。46例（68.7 \%) で推定可能で，両親が大部分を占め，他の 感染源も含め患児と密接な接触機会を有してい た。感染源の排菌状況をみると少数ながら排菌 の認められなかった例や微量排菌例もあるが, 多くは大量の排菌を認め, 強い感染力を有して いることがわかる。

\section{考察}

最近 5 年間に当科で診断した 67 例の小児結核 患者について検討し，小児結核の現状ならびに 問題点の把握を試みた。その結果乳幼児結核患 者は大部分が BCG 未接種者であり，できるだ け乳児期早期に BCG 接種を行い発病予防に努 めることが重要と思われた11,22。また感染から発 病までの期間が短いので感染源が発見された時 点で既に発病していることも多く重症化を防ぐ ため感染源発見後一刻も早い家族検診の実施が 望まれる。これに対し年長児の場合，感染から 発病までの期間は比較的長いので家族検診は感
表 2 感染源の有無と排菌状況

\begin{tabular}{|c|c|c|c|}
\hline \multicolumn{2}{|l|}{ 怒染源の有燕 } & \multicolumn{2}{|c|}{ 染源の排菌状沉 } \\
\hline あり & $46(68.7 \%)$ & 不明 & $2(4.3 \%)$ \\
\hline 父 & 20 & 跧性 & $7(15.2 \%)$ \\
\hline 母 & 12 & 培苝のみ隔性 & $4(8.7 \%)$ \\
\hline 相父母 & 6 & 堡沫隔性 & $33(71.7 \%)$ \\
\hline 权父・叔母 & 5 & 不明 & 4 \\
\hline 保母 & 2 & G $1 \sim 2$ & 4 \\
\hline ※人 & 1 & $G 3 \sim 5$ & 7 \\
\hline 不明 & $21(31.3 \%)$ & $\mathrm{G} 6 \sim 10$ & 18 \\
\hline
\end{tabular}

染源発見 $2 \sim 3$ 力月後に実施するのが妥当であ ろう。また年長児では BCG 接種歴があっても 接種から 10 年近く経過している例が多く $\mathrm{BCG}$ 接種技術や予防効果持続期間の検討も必要と考 えられた。いずれにしても家族検診はただ単に 機械的に実施すればよいというものではなく， 感染源の排菌量や排菌期間 - 児の BCG 接種歴 などを考慮して実施時期や実施方法などを検討 し効率的な対応を行い，必要な児には発病予防 や治療を的確に行うことが重要である ${ }^{3) \sim 5) 。 ~}$

\section{文 献}

1) 橋本達一郎 : BCG 接種の現状と問題点. 結核, $62: 51-60,1987$.

2 ) 松島正視：小児科医のための結核情報前編； BCG 接種をめぐって。少科 $30: 667-672$, 1989.

3 ) 青木正和: 結核症の化学予防について. 命令入 所㧍よび初感染結核の取扱いとその解説。厚生 省保健医療局結核・感染症対策室監修, 第一版, 財団法人結核予防会，東京，p 90-116, 1989.

4) 青木正和：結核管理技術シリーズ 2 , 結核集団 感染, 増補改訂版, 財図法人結核予防会, 東京, 1988.

5 ) 亀田和彦, 久池井暢，堀井富士子，他：結核患 者の家族検診 (第 4 報) 一患者登録後 4 年目の調 査一。結核 $52: 447-453,1977$. 